\title{
School Based Assessment: Will it Really Change the \\ Education Scenario in Bangladesh?
}

\author{
Mariam Begum \\ Institute of Education and Research \\ Dhaka University \\ Dhaka-1000, Bangladesh \\ E-mail: mariam_chowdhury53@yahoo.com \\ Sabrin Farooqui \\ Faculty of Education and Social Work \\ University of Sydney \\ NSW 2006, Australia \\ E-mail: s.farooqui@edfac.usyd.edu.au
}

\begin{abstract}
In Bangladesh, the system of assessment has always been guided by curriculum though the system only covered learners' ability of memorization and comprehension skills. Other categories of skills in the knowledge like application, analysis, synthesis and evaluation are hardly included in the assessment. Besides, some of the essential qualities such as oral presentation, leadership, tolerance, co-operative attitude, school behavior, co-curricular activities, and social values are not included in the assessment system. As a result, learners' trend to rely heavily on their memorization skill leads them to become crippled lacking required excellence to contribute fruitfully to the society. The government of Bangladesh has timely envisaged the reservation of its education system and has justly adjudicated the School Based Assessment (SBA) aspiring learners' holistic development. SBA has been implemented in junior secondary levels of general education in June, 2007. This paper reveals the current situation of the recently applied assessment system through a study of a group of teachers of secondary level and SBA trainers. It will discuss the issues that emerge from the arguments of the scholars that they hold regarding SBA and its potentiality in the context of Bangladesh.
\end{abstract}

Keywords: School based assessment, Secondary school, Evaluation, Language policy, Policy implementation, Teaching language

\section{Introduction}

Education is a vehicle of social progress and socio economic transformation. It is the process by which people acquire knowledge, skills, habits, values or attitudes. The word 'education' is also used to describe the results of educational process. It is conceived to be an on going process. During this process it is often required to measure the progress of the learners, how far the educational changes occurred among them or how these changes have been organized.

In Bangladesh, secondary education is one of the most important and biggest sub-sectors in education having huge number of institutions and teachers. The rate of enrolment in secondary sub-sector increased significantly in last decade but in terms of quality, it is not up to the mark. As mentioned by National Curriculum and Textbook Board (NCTB)

Too many of our young people are dropping out of school each year. Too many are not going on to the next year. Too many of them are not able to be present for the Board examinations. Too many are failing. These must be changed. The Community is concerned about the standards of behaviour and the values of our young people. The school has an important role to play in relation to these aspects of students' development. (NCTB, 2006, p. ii)

To reform and bring positive changes in the secondary curriculum, the Government, Non-Government Organisations (NGOs) and other educational organizations have been putting efforts since 1990s. The government has recently taken a lot of initiatives to ensure the quality of education. The recent innovations in teaching and learning at the secondary level in Bangladesh have received considerable attention. Generally, in Bangladesh secondary schools, the examinations focus on assessing students' ability to memorize what they have been taught. But to ensure a quality education, proper 
assessment is needed along with an effective syllabus. In June, 2007, the government asked the schools across the country to carry out School Based Assessment (SBA) of students of grade VI-IX, instead of the existing evaluation system that depends solely on examination. With the introduction of the new assessment system, students' promotion to the next class level will depend not only on examination results but also on their performance throughout the year and on their personal development. The purpose of this study is to find out the current situation of SBA, teacher trainers' and teachers' attitude towards it and the possibility of its success in bringing change in education in Bangladesh.

This paper begins with an introduction to the current assessment system in Bangladesh. The introduction is followed by a brief description of SBA. Then it reports on a study where issues of different aspects of SBA were raised through interview survey (Wiersma \& Jurs, 2005) and semi-structured interviews with secondary school teachers. Data have also been collected through document analysis. The paper ends with a discussion and some recommendations for successful implementation of this new assessment system.

\section{Background}

\subsection{Secondary education in Bangladesh}

There are three stages in the structure of institutional education in Bangladesh i.e. primary, secondary and higher education. Primary education is a five-year cycle from grade I-V. This study will focus on secondary education which comprises three year junior secondary from grade VI-VIII, two year secondary from grade IX and X, and two year higher secondary from grade XI-XII. Higher secondary is followed by higher education in general, technical, technology and medical education streams with four/five year graduation. The secondary education sub-sector in Bangladesh is quite large. According to the Bangladesh Bureau of Educational Information and Statistics (BANBEIS), the number of secondary school is 18500 having 238158 teacher and 7398552 students in the year 2006 (BANBEIS, 2007). Students sit for Secondary School Certificate Examination (SSC) at the end of year 10. They sit for Higher Secondary Certificate (HSC) examination at the end of year 12. SSC reflects 10 years of education starting from year 1 to 10. HSC plays a vital role in students' life since it prepares the learners for higher education. Till present, both these high stake examinations emphasize students' memorization skill and the power to reproduce them in examination hall.

According to the language of instruction, the schooling system of Bangladesh can be divided into two systems -Bangla medium schools and English medium schools. English language courses are mandatory for students studying in schools of both systems. Proficiency in English has become mandatory for success in both studying and working since English is currently the undisputed language of science and technology. In business and industry, workers are increasingly expected to develop proficiency in English. English proficiency is now required for most professional employment. "Being nationally competent in English is one necessary condition if Bangladesh is to move up the long curve of economic growth from its low starting point" (Imam, 2005, p.474).

The Government of Bangladesh started making changes in ELT policies to improve English language teaching in the country since it was clearly evident that students' English language skill could not be improved with the existing ELT policies. The Government and the international agencies have invested increasingly large amounts in last decade for the expansion and improvement of English language teaching and learning provisions. The English Language Teaching Improvement Project (ELTIP) was among the initial projects that aimed to improve the quality of English Language teaching in secondary and higher secondary education in Bangladesh. It was co-funded by the Bangladesh government and Department for International Development (DFID) of United Kingdom and was run by the British Council and NCTB. ELTIP introduced communicative textbooks in the year 2000 up to the higher secondary level in Bangladesh. The new curriculum stressed the need for students to learn to communicate in English rather than to just master the structure of the language. Although the policy and the textbooks changed to a communicative method in the year 2000, the pictures of English language classrooms still reflects the traditional teaching style. Teachers still stress the development of reading and writing skills for the purpose of getting good results in examinations (Hasan, 2004). Rahman (1999) states "Notebooks and guidebooks are a lifeline to most learners and the negative backwash effect of the examination on teaching and learning strategies complete the cycle of monolithic pattern of knowledge and education" (p. 109)

\subsection{School Based Assessment (SBA)}

Secondary Education Sector Improvement Project (SESIP) is one of the various improvement projects that have recently started running at the national level with donor assistance. It is a Tk 490 crore project which is jointly funded by Asian Development Bank (ADB) and the Government of Bangladesh. It recommended introducing a uni-track curriculum and the SBA system from 2006. SBA is the assessment of students' progress which occurs, on an ongoing basis during the year, as an important part of the students' learning. With SBA, teachers give regular feedback to their students to help them learn better. It has been implemented with the intention of developing students' thought process, their ability to solve problems. It will also focus on students' personal development and communicative ability.

In Bangladesh, students' assessment system is based on year final examination. Their reports and decisions about their 
promotion to the next class level are based only on their performance on the school examinations conducted at the end of each year. These examinations test the students' ability to answer written questions in a given time, remembering what they have learned. This can not assess many of the very important objectives of secondary education i.e. solving problems, orally expressing thoughts clearly, learning to behave appropriately and developing sound personal and social values. The new assessment system has been introduced to Bangladeshi schools so that these broader objectives are assessed. NCTB (2006) published a Teachers' Guide for SBA (2006) which says "SBA VI-IX is being introduced to raise the standards of secondary education to international standards and to ensure overall assessment in respect of the school behavior and personal and social values of students" (p.ii).

With SBA, student assessment at classes will include the following three areas

- $\quad$ Students' coursework-the school work they do in the classroom and at home during the year. Six different areas of student course work have been identified. The areas are class tests, class work, home work, assignments, oral presentations and group work. Each of these areas will contribute to the students' overall course work mark.

- Students' personal development-their behaviour within the school, their development of personal and social values and their participation in co-curricular activities of the school.

- $\quad$ Students' performance in end-of-year examinations.

(A sample of teachers' mark book for coursework has been given in Appendix A)

Based on the following criteria, a student will be assessed through the year in each subject

a. Attendance in class and interest in learning

b. Assessment (class wise)

c. Assignments (individual/in group)

d. Behaviour, values and honesty

e. Presentation of speech/individual and group discussions

f. Leadership qualities

g. Discipline

h. Participation in cultural activities

i. $\quad$ Performance in sports and games

j. $\quad$ Practical classes in science subjects

(NCTB, 2006, p. VI)

Each class teacher is expected to arrange, each term, a meeting of all subject teachers of his/her class to discuss and agree upon a mark for school behaviour for each student. It is considered important that teachers keep good record of students' performance on SBA. The Head teacher must make sure that teachers keep good records. Teachers can help one another in planning their assessment and in planning their record keeping.

\section{Literature Review}

Assessment plays a central role in teaching and learning. In many countries, where teaching has become more communicative, testing remains same within the traditional pattern consisting of discrete items, lower order thinking and a focus on form rather than meaning (Brown, 2004). Even with an effectively communicatively oriented teaching program, the tests given to assess performance tend to emphasize the learners' knowledge of separate grammatical points because these are the kinds of tests and test items that exist (Eckes et al. 2005). If students are given such tests, then they will want to be taught in a way that ensures them a 'pass' which defects both the teachers' and the students' goal of enabling the students to actually express themselves in everyday communicative events. In Bangladesh, the term-final or the year final examination and the SSC, HSC examinations are all traditional tests. Critics of such traditional tests argue that the test preparation requires drilling students on a narrow set of skills covered on the test which may turn to be harmful to their educational development and thinking (Crocker, 2005; Hillocks, 2002; Kohn, 2000). The prime objective of language assessment reform is to build communicative skills that are important for performing real-life like tasks rather than to train the students on grammar rules and make them skillful in translating written texts (Eckes et al., 2005). The new SBA system emphasizes on regular attendance in the classroom, developing students' oral communicative skill in English, developing other characteristics like working in a group, doing field work and so forth. Torrance (1995a) states that if higher order skills and competencies such as problem-solution, investigation, analysis are included in the assessment system, the quality of teaching will be improved with respect to both curriculum coverage and teaching method (p.44).

In many cases, like Bangladesh, new assessment system is implemented to achieve the objective of new educational 
curriculum. Petrie (1987, in Cheng 1999) says that "It would not be too much of an exaggeration to say that evaluation and testing have become the engine for implementing educational policy" (p. 254). These days, language test is taking the turn from mere examination room based test to a form that no longer involves the ordeal of a single test performance in a specific period of time. But improving assessment method in order to improve teaching-learning method is a major step. According to Torrace (1995b), such a reform concentrates on how, and by whom, new educational goals are to be identified, how they are to be encapsulated in the design of new assessment, how those designs are to be operationalized, whether or not teachers are sufficiently aware of and skilled in the pursuit of new goals, and, if not, what sort of training and material support might be provided for them (and, once again, by whom) (p. 150)

Torrace (1995a) conducted a comprehensive study on General Certificate of Secondary Education (GCSE) which was introduced in secondary schools in England and Wales in 1986. He shows that all secondary school teachers involved with examination class had to engage to some degree in school based assessment. It was introduced to improve the secondary school curriculum and the classroom teaching. The study shows that teachers have engaged most effectively with new assessment system when the changes have derived from clearly understood changes in the curriculum. Chapman \& Snyder (2000) also argue that the new assessment systems are implemented since it can be effective for improving instructional practice but such a mechanism can fail to understand the conditions that need to be met in order to have the desired impact on teachers' classroom practice. They also argue that teachers can not adjust to the changes in assessment all the time. They further say that "Even if they understood the examination requirements at a cognitive level, they were often unable to make the necessary changes in the classroom to improve their students' performance" (p. 462). Együd, Gál, \& Glover (2001) also suggest that the language teachers need to be involved in different stages of the design and validation of a language examination or other assessment system through an ongoing support system. Torrace (1995a) concludes his study by saying :

New approaches to assessment are certainly a necessary, but not a sufficient mechanism for change within educational systems. Implementation must proceed in tandem extensive school-based exploration of the problems and possibilities of new approaches to assessment if our ambitions for them are to be realized (p.56)

An assessment system not only affects the learning and teaching but it also affects the society as a whole. According to McNamara (2000), the impact of assessment can be complex and unpredictable. While talking about the impact of assessment, he also points out "part of the impact of the reform was to open the door to abuses of the assessment process by wealthy families, who could afford to hire private tutors to coach their children through the projects they had to complete in order to gain the scores they needed to enter the university of their choice" (p.75)

These studies reveal that the success of these changes greatly depends on whether or not the teachers feel they have the time, knowledge, material to achieve the goals and whether they received the training and encouragement to bring the change. A good number of researches and publications have focused on change in language assessment system, its impact and possibilities in developed countries. Rarely there is any research that focuses on the impact of such assessment system in developing countries.

\section{Research Questions}

The study had the following research questions

1. What is the existing situation of the new assessment system?

2. What are the attitudes of the teachers toward SBA?

3. Are the teachers well equipped to accomplish the task efficiently?

4. What are the existing challenges the teachers face while implementing the SBA?

\section{Research Methodology}

In this research, data were collected from four SBA trainers and 18 secondary teachers- seven from sub urban and 11 from urban areas. The participants were selected following 'Typical Case Sampling' which is a type of purposive sampling strategy (Wiersma \& Jurs, 2005). The teaching experience of the teachers varied from 6-22 years and their age ranged from 34 to 52 years. All the teachers were selected purposively from urban and semi urban areas. Dhaka, the capital city and Savar, a semi urban area were selected with the idea that whatever changes take place in the field of education should start with the capital city and its sub urban areas. The trainers of SBA were just starters as trainers and they were selected from urban training centers.

Both qualitative and quantitative data were collected through interview survey, semi-structured interviews and document analysis in this research. Two separate questionnaires of open ended questions were made for the teachers and the trainers (see the Appendix B and C). The questionnaires were distributed among 18 teachers and four teacher trainers. Following the survey, semi-structured interviews were taken with eight of the teachers. The interview served the purpose of exploring further the teachers' opinion and the current situation of SBA. Most of the questions focused on participants' understanding of SBA and their attitude towards it. There were a number of questions that asked 
participants' idea and recommendation for its successful implementation. The trainers were also asked about their view about the potentiality and steps taken for successful implementation of the new assessment system in Bangladesh. The profile of the participants chosen for the interview is provided in Appendix D. These participants have been given pseudonyms to maintain their anonymity. Their names are used when their views are noted below. The interviews were conducted in the native language 'Bangla' since teachers' imperfect English might limit the information they provided. These were transcribed and translated later. One of the authors personally derived the opinions in a very congenial atmosphere so that the situation may not seem to be artificial or threatening one. In both the cases opportunities were created in favor of their speaking freely. In a very informal setting they were asked to answer the questions on various aspects of SBA. The opinions are interpreted without changing their original theme and some others are quoted as they are. Information were also collected from recent articles, syllabus, curriculum documents and government reports. The documents provided a backdrop for more detailed data collection through interview survey and semi-structured interviews with informants.

The themes emerged from an examination of the data. All the sources of information i.e. the answers to interview survey, the transcripts of the semi-structured interview and the documents were repeatedly read through. Categories were developed using the Constant Comparative Method (Lincoln \& Guba, 1985).

Recurrent themes regarding the SBA system were identified and the information have proved to be very valuable in understanding the issues under study.

\section{Findings}

The findings have been summarized under two main categories i.e. present situation of SBA and attitudes towards the implementation of the new assessment system.

\subsection{Present situation of SBA}

SBA has been started in the respective schools of all the participants but out of the 18 teachers of secondary level, only 10 have got training on SBA. Their head teachers got training and informed them about the marking scheme of SBA. Head teachers have also been provided training for three days to get an idea about SBA so that they can assist the subject teachers to conduct the activities of assessment and to prepare the report. These Head teachers are bestowed with the responsibility to check every subject teacher's record keeping.

Trainers mentioned that assurance of implementation process can be understood through a chain of activities conferred upon the officials of different ranks. In addition to that, occasional visits to schools will be organized by NCTB to monitor the assessment activities. But all of the participants said that no District Education Officer (DEO) ever visits their schools. None of them could give any satisfactory answer on the issue of justice. Regarding ethical issues, trainers expressed their view that every precaution has been taken but nevertheless they were uncertain whether any case of injustice can be resisted.

Regarding the regular attendance, they informed that only the class teacher can ensure that because 'we do not take their attendance in every period, so we copy it from the class teacher' (Amir). Most striking information gathered from these two teachers was that for their convenience they have changed the marks scheme and later on distributed the marks according to the chart provided for keeping records.

\subsection{Attitude towards the implementation of the new assessment system.}

Eight participants engage their students in group work and assess their students' oral skill and they do not deem this an extra load. They presume that if they properly practice the activities prescribed in SBA, this will undeniably help our students to improve their overall skill progression. One of the participants quickly points out:

Since the term final examination test students' reading and writing skills in English, neither the teachers nor the students feel the urge to do speaking and listening activities in English language classes. If implemented properly, SBA will help to develop students' listening and speaking skills. It won't be any obstruction. (Rahima)

All of the participant teachers are engaged in providing private tuition to the students though they confirmed the idea that there is no possibility of students becoming victims to their teachers. The junior teachers were more positive in the use of SBA than the senior ones. If the teachers can plan their activities accordingly, SBA will be able to improve the quality of education of Bangladesh.

Most of the participants mentioned that teachers for the first time may not be able to accept the change positively and easily because in Bangladeshi context, teachers rarely practice oral presentation or do group works with the students. It will impose on them extra load of work. It seems to them very difficult to maintain after taking 6-7 periods everyday. Classes usually being large, it has become an extra load for them to maintain all the categories of activities. They are in the opinion that if they try to do all those activities in the class, they will not be able to complete the syllabus for the $70 \%$ marks which they consider more important than the 30\% marks. All of them check their students' home work and assignments during their off periods nevertheless they do not have enough off periods. Throughout the year, 
scheduled/unscheduled interruptions of classes take place. Political disruption, natural disasters, closures for board examinations and a range of scheduled holidays often disrupt the academic calendar. In this process it is very difficult to teach the students, as class time does not permit to do all the activities mentioned in SBA. It is very difficult to manage in a large class. In short, this is definitely an extra burden for the teachers.

Six of the participants believe that the current assessment system may make way for widespread corruption by fuelling the profiteering trend of private tuition. As most teachers of city area are engaged in private tuition, the issue of students being victimized can not be denied. It depends on individual teacher's sense of justice. As Fatema says:

I am engaged in private tuition, most of the teachers are; so there is every possibility that any student may fall prey to any teacher's whim. I don't agree with the theme that SBA will help students' overall development. Sometimes teachers try to do some group work or oral exercises but they will not be successful in developing English language skills.

Another negative aspect of SBA has been pointed out by many of the participants. As Nirmal points out "If we do not give high marks to the children of locally influential people, they may come down on us. We may come under their attack"

\section{Discussion and Recommendations}

The findings show that trainers are very optimistic about changing the assessment system successfully. The teachers are divided into their opinions regarding the positive impact of SBA system on current education system. The findings show that although the government has already implemented the new assessment system, most of the teachers have not got the training necessary for implementing such a project. Untrained teachers will have a poor understanding of the ideas which will lead them to their inability to distribute the marks effectively. If these teachers try to implement such a new system, the system will collapse. If the SBA is implemented without providing adequate training to the teachers, a huge gap will be created between ministerial style and classroom reality.

Although teachers and trainers are quite optimistic about bringing a positive change in education through SBA, there is a widespread apprehension that teachers will misuse this to give high numbers to the students who take private tuition. It is important to implement policies that suit the local culture.

To ensure proper evaluation of a student, recommendations have been provided below

a) academic supervisors should be given this responsibility of monitoring

b) head teachers should call meeting and check all teachers' record keeping in each term

c) a committee can be formed in each school to check the records

d) guardians should be aware of the fact that their children may not fall victim to any teacher, if suspected, guardians should place immediate complain to the head teacher

e) Head teachers should sit for a guardian's meeting after each term and try to solve the complaints placed by the guardians.

f) An element of guidance and counseling may be introduced. It will provide opportunity to know teachers' problems while implementing the new assessment system.

These are some of our reflections conceived through this survey, it is our assumption that if the suggestions can be maintained properly only then we can foresee desirable outcome from SBA.

\section{Conclusion}

Educational change is a complex phenomenon. The success of the new assessment system will depend on proper management of resources and manpower. The study reveals some significant facts about teachers' knowledge and integrity of implementing this new system of assessment. The number of participants was small but most of them provided similar type of information. As a developing country, Bangladesh has to depend on donor agencies. Since the government of Bangladesh and the donor countries have been pouring huge amount of money to bring changes in secondary education, we hope that the government and the ministry of education will frame policies and implement practices after adequately considering the contextual factors so that they can succeed to achieve the targets of implementing the new assessment system. Our previous experiences of various foreign aided projects make us absolutely dubious about the credibility of SBA as we can be unquestionably irrefutable that not all the foreign prescriptions act favorably in the socio-cultural as well as political reality of our society. According to Rahman, Kabir and Afroze (2006), a program needs to work within the social and contextual realities of their environment. If the Bangladesh Government commits to bring change in the assessment system and can find ways to overcome the local constraints, the step towards changing the assessment will definitely be successful. It is our whole hearted expectation that SBA will bring about noteworthy changes among the students making them more capable to suit to the rapidly changing contemporary society. 


\section{References}

BANBEIS (2007). Bangladesh Bureau of Educational Information and Statistics [Online] Available: http://www.banbeis.gov.bd (October 10, 2007)

Brown, H. D. (2004). Language Assessment Principles and Classroom Practices. New York: Pearson Education.

Chapman, D. W., \& Snyder, C. W., Jr. (2000). Can high stakes national testing improve instruction: Reexamining conventional wisdom. International Journal of Educational Development 20, 457-474.

Cheng, L. (1999). Changing assessment: Washback on teacher perceptions and actions. Teaching and Teacher Education 15(2000), 253-271.

Crocker, L. (2005). Teaching for the test: How and why test preparation is appropriate. In R.R Phepls (Ed.), Defending Standardized Testing (pp. 159-174) Mahwah N.J.: L. Erlbaum Associates.

Eckes et al. (2005) Progress and problems in reforming public language examinations in Europe: Cameos from the Baltic States, Greece, Hungary, Poland, Slovenia, France and Germany. Language Testing 22 (3), 355-377.

Együd, G., Gál, I. \& Glover, P. (Eds). (2001). English language education in Hungary, part III: training teachers for new examinations. Budapest: The British Council Hungary.

Hasan, M. K. (2004). A linguistic study of English language curriculum at the secondary level in Bangladesh: A communicative approach to curriculum development. Language in India 4 (8). [Online] Available: http://www.languageinindia.com/aug2004/ html (October 10, 2007)

Hillocks, G, Jr. (2002). The Testing Trap. NY Teachers College: Columbia University.

Imam, S. R. (2005).English as a global language and the question of nation-building education in Bangladesh. Comparative Education 41(4) 471-486.

Kohn, A. (2000). Standardized testing and its victims: Inconvenient facts and inevitable consequences. Education Week 60(46).

Lincoln, Y. S., \& Guba, E. G. (1985). Naturalistic inquiry. Beverly Hills , CA :Sage.

McNamara,T. (2000). Language Testing. Oxford University Press: New York.

NCTB (2006) Teachers' Guide For School-Based Assessment in Classes VI-IX. Ministry of education:Dhaka.

Rahman, A. (1999). Educational innovation and cultural change:A Bangladeshi perspective. The Dhaka Universities Studies 56(1), 107-130.

Rahman, A.,Kabir, M. M. \& Afroze, R. (2006). Effect of BRAC-PACE Training of English Language Teachers of Rural Non-Government Secondary Schools.BRAC: Dhaka.

Torrace, H. (1995a). Teacher involvement in new approaches to assessment. In H.Torrance (Ed.), Evaluating Authentic Assessment (pp. 44-56). Philadelphia: Open University Press.

Torrace, H. (1995b). The role of assessment in educational reform. In H. Torrance (Ed.), Evaluating Authentic Assessment (pp. 144-165). Philadelphia: Open University Press.

Wiersma, W. \& Jurs, S.G (2005). Research Methods in Education, an Introduction. Boston : Pearson.

\section{Appendixes}

\section{Appendix A}

Recording Student Performance Within SBA VI-IX Teacher's Mark Book for (Subject Name) Course Work, Team 1

Table A1. Teacher's Mark book

\begin{tabular}{|l|l|l|l|l|l|l|l|}
\hline $\begin{array}{l}\text { Students' } \\
\text { Names }\end{array}$ & $\begin{array}{l}1 . \text { Class } \\
\text { Test }\end{array}$ & $\begin{array}{c}\text { 2.Class Work } \\
\text { and Practical } \\
\text { Work }\end{array}$ & 3. Homework & 4.Assignmnet & $\begin{array}{c}\text { 5. Oral } \\
\text { Presentation }\end{array}$ & $\begin{array}{c}\text { 6. } \\
\text { Group } \\
\text { Work }\end{array}$ & $\begin{array}{c}\text { Total } \\
\text { Course } \\
\text { work }\end{array}$ \\
\hline & & & & & & & \\
\hline
\end{tabular}

Source: NCTB, (2006) 


\section{Appendix B}

Questionnaire for Trainers

1. When did you start training the teachers for SBA?

2. So far how many teachers did you train?

3 Did you take training for SBA before providing training to the teachers? If yes, for how many days? Who were your trainers?

4. Do you think that SBA will be able to improve the quality of secondary education in Bangladesh?

5. Don't you think that this will be an extra load for the teachers?

6. How do you ensure that teachers are doing all those activities in the class when they get back to school?

7. Do you provide training for the head teachers also? If yes, for how many days?

8. In your opinion would it be possible to train all the secondary education teachers before 2009? If not, how are you going to cover this large number?

9. Do you think that SBA will bring about a positive impact on the students' achievement? If yes, how?

10. Don't you think that teachers can victimize any student? If no, how do you ensure that?

20. Do you agree with the idea that SBA will help students' overall development?

21. In your opinion, is there any possibility of students being victimized?

22. Is it possible to implement SBA in your school?

23. Do you consider this an extra work? If yes, why?

24. How can we ensure the ethical issues?

\section{Appendix C}

Questionnaire for Teachers

1. When did you start SBA in your school?

2.Have you got any training on SBA? If yes, for how many days?

3. What idea do you possess about the course work?

4. What type of activities do you engage your students in?

5. How do you evaluate your students' oral skill?

6. Do you engage your students in group work in class? If yes, how do you assess each student's activity in a group ?

7. Do you assign them any home work? If yes, what kind of home work do you assign them?

8. When do you check your students' home work?

9. Could you please give one example of assignment that you used for your students?

10. Do you keep a regular record of your students? If yes, when do you prepare it?

11. So you use any other material instead of the textbook? If yes, please name them.

12. How do you keep record of your students' behavior?

13. How often do you take class test in a term?

14. Does your school organize cultural activities? If yes, how often?

15. Do you have ideas about all the 6 areas on which you have to mark your students? If yes, please mention them.

16. Do you discuss with your colleagues before putting marks for your students? If yes, how often?

17. Do you get help from your head teacher while preparing the report? If no, where from do you get support?

18. Are you engaged in private tuition? 
Appendix D

Table D1. Background of Survey Participants (Teachers)

\begin{tabular}{|l|l|l|l|l|}
\hline Participant & Sex & Age & Teaching Experience & Type of School \\
\hline Fatema & F & 34 & 6 & urban \\
\hline Ali & M & 45 & 16 & urban \\
\hline Shafiq & M & 35 & 6 & sub-urban \\
\hline Rahima & F & 50 & 20 & urban \\
\hline Nirmal & M & 38 & 10 & urban \\
\hline Kajol & F & 52 & 20 & urban \\
\hline Taleb & M & 47 & 19 & sub-urban \\
\hline Amir & M & 36 & 8 & sub-urban \\
\hline
\end{tabular}

